\begin{tabular}{l|l} 
Totaice & e-ISSN: 2655-9404 p-ISSN: 2721-8376 \\
Vol. 4 No. 1, Februari 2021 & DOI: 10.20473/ntr.v4i1.23553 \\
\hline
\end{tabular}

Article history: Submitted 1 Desember 2020; Accepted 14 December 2020; Available online 1 February 2021.

\title{
Kajian Normatif Kedudukan Badan Usaha Milik Desa Sebagai Subyek Hukum
}

\author{
Shara Mitha Mahfirah dan Adista Paramita \\ shara.mitha.mahfirah-2019@fh.ac.id dan adistaparamita86@gmail.com \\ Universitas Airlangga
}

\begin{abstract}
Jokowi-Jusuf Kalla's Nawacita programme, especially the third Nawacita program, namely "Building Indonesia from the periphery by strengthening regions and villages." Give a mandate to the Village Ministry, the Development of Undeveloped Areas, and Transmigration to oversee the implementation of Law Number 6 of 2014 in a systematic, consistent and sustainable manner with facilities, supervision, and assistance. One of the interesting programs from Law Number 6 of 2014 is the mandate for the establishment of Village-Owned Enterprises (hereinafter referred to as BUMDesa). In Indonesia, business entities are classified into two, namely, legal entities and non-legal entities. In the laws and regulations governing BUMDesa, it is not clearly stated which BUMDesa is a business entity. So that it becomes an obstacle for BUMDesa in developing its business and taking legal actions with third parties. The issuance of Law Number 11 of 2020 concerning Job Creation, gave new legal status to BUMDesa, namely as Legal Entity. The purpose of this research is to give insight on how BUMDesa as a legal subject.

Keywords: Village Owned Enterprises; Legal Subjects; Legal Entities.
\end{abstract}

\begin{abstract}
Abstrak
Program Nawacita Jokowi-Jusuf Kalla, khususnya Nawacita ketiga, yaitu "Membangun Indonesia dari pinggiran dengan memperkuat daerah dan desa." Memberikan mandat kepada Kementrian Desa, Pembangunan Daerah Tertinggal, dan Transmigrasi untuk mengawal implementasi Undang-Undang Nomor 6 Tahun 2014 secara sistematis, konsisten dan berkelanjutan dengan fasilitas, supervisi, dan pendampingan. Salah satu program yang menarik dari Undang-Undang Nomor 6 Tahun 2014 adalah amanat dibentuknya Badan Usaha Milik Desa (disingkat BUMDesa). Badan Usaha di Indonesia digolongkan dua bagian yaitu badan usaha berbadan hukum dan badan usaha yang tidak berbadan hukum. Dalam peraturan perundang-undangan yang mengatur tentang BUMDesa tidak disebutkan secara jelas BUMDesa tergolong badan usaha yang mana. Sehingga menjadi hambatan bagi BUMDesa dalam mengembangkan usahanya dan mengadakan perbuatan hukum dengan pihak ketiga. Dikeluarkannya Undang-Undang Nomor 11 Tahun 2020 tentang Cipta Kerja, memberikan status hukum baru bagi BUMDesa, yaitu sebagai Badan Hukum. Konstruksi Yuridis Bumdes sebagai subyek hukum menarik menjadi poin penting dalam penelitian untuk mengetahui dan memahami bagaimana konstruksi tersebut dapat diterapkan di masyrakat.

Kata Kunci: Badan Usaha Milik Desa; Subyek Hukum; Badan Hukum.
\end{abstract}

\section{Pendahuluan}

Copyright $\odot 2021$ Universitas Airlangga

Ketentuan Pasal 1 ayat 1 Undang-Undang Nomor 6 Tahun 2016 tentang

Desa (selanjutnya disebut sebagai UU No 6 Tahun 2014) menyebutkan definisi 
desa sebagai berikut:

"Desa adalah desa dan desa adat atau yang disebut dengan nama lain, selanjutnya disebut Desa, adalah kesatuan masyarakat hukum yang memiliki batas wilayah yang berwenang untuk mengatur dan mengurus urusan pemerintahan, kepentingan masyarakat setempat berdasarkan prakarsa masyarakat, hak asal usul, dan/atau hak tradisional yang diakui dan dihormati dalam sistem pemerintahan Negara Kesatuan Republik Indonesia".

Desa merupakan unit terkecil dari negara yang terdekat dengan masyarakat dan secara riil langsung menyentuh kebutuhan masyarakat untuk disejahterakan. Sebagai wakil negara, desa wajib melakukan pembangunan baik pembangunan fisik maupun pembangunan sumber daya manusia sebagai upaya peningkatan kualitas hidup dan kehidupan untuk sebesar-besarnya kesejahteraan masyarakat desa. ${ }^{1}$ Permasalahan lain yang sering dihadapi dengan tidak berkembangnya ekonomi berbasis pedesaan adalah kurangnya sumber daya manusia yang mampu melihat peluang. Hal ini berimplikasi pada ketergantungan terhadap bantuan Pemerintah dan tidak mandiri. ${ }^{2}$

Eksistensi desa merupakan konsekuensi penyelenggaraan pemerintahan di Indonesia yang menganut asas desentralisasi yang mana memberikan kesempatan seluas-luasnya kepada daerah untuk menyelenggarakan otonomi daerah. BUMDes merupakan pilar kegiatan ekonomi desa yang berfungsi sebagai lembaga sosial yaitu berpihak kepada kepentingan masyarakat dalam penyediaan pelayanan sosial dan menjalankan fungsi komersial yaitu bertujuan mencari keuntungan melalui penawaran barang dan jasa ke pasar. BUMDes sebagai badan hukum dibentuk berdasarkan perundang-undangan dan sesuai kesepakatan masyarakat desa. ${ }^{3}$ Dengan demikian diharapkan segala potensi yang terdapat pada daerah dapat diusahakan secara optimal.

\footnotetext{
${ }^{1}$ Maria Rosa Ratna Sri Anggraeni, 'Peranan Badan Usaha Milik Desa (BUMDES) Pada Kesejahteraan Masyarakat Pedesaaan Studi Pada Bumdes Di Gunung Kidul' (2016) 28 Jurnal Modus. [156].

${ }^{2}$ Rosita Adiani, 'Penguatan BumDes Dengan Status Badan Hukum' (2020) <http:/ fis.unj. ac.id/sosiologi/2020/01/artikel-pengabdian-2019/ > accessed 20 October 2020.

${ }^{3}$ Muhammad Adib Junaidi, 'Peran Badan Usaha Milik Desa (BUMDes) Dalam Penguatan Ekonomi Di Desa Kedung Turi Kecamatan Taman Kabupaten Sidoarjo' (Universitas Airlangga Surabaya 2018).[3].
} 
Kehadiran Kementrian Desa, Pembangunan Daerah Tertinggal, dan Transmigrasi mempunyai mandat untuk menjalankan Program Nawacita JokowiJusuf Kalla, khususnya Nawacita ketiga, yaitu "Membangun Indonesia dari pinggiran dengan memperkuat daerah dan desa." Salah satu agenda besarnya yaitu mengawal implementasi Undang-Undang Nomor 6 Tahun 2014 secara sistematis, konsisten dan berkelanjutan dengan fasilitas, supervisi, dan pendampingan. Pendampingan desa bukan hanya sekedar menjalankan amanat Undang-Undang Nomor 6 Tahun 2014, tetapi juga modalitas penting untuk mengawal perubahan desa untuk mewujudkan desa yang mandiri dan inovatif. ${ }^{4}$

Dalam ketentuan Pasal 1 angka 6 UU No. 6 Tahun 2014 disebutkan tentang definisi Badan Usaha Milik Desa, yaitu:

“Badan Usaha Milik Desa, yang selanjutnya disebut BUM Desa, adalah badan usaha yang seluruh atau sebagian besar modalnya dimiliki oleh Desa melalui penyertaan secara langsung yang berasal dari kekayaan Desa yang dipisahkan guna mengelola aset, jasa pelayanan, dan usaha lainnya untuk sebesar besarnya kesejahteraan masyarakat Desa".

Berdasarkan definisi diatas dapat kita simpulkan bahwa BUMDesa adalah suatu badan usaha yang berorientasi pada kesejahteraan masyarakat, namun tidak dijelaskan kedudukan hukumnya lebih lanjut apakah BUMDesa merupakan suatu badan usaha yang berbadan hukum atau badan usaha yang tidak berbadan hukum.

BUMDesa lahir sebagai suatu pendekatan baru dalam usaha peningkatan ekonomi desa berdasarkan kebutuhan dan potensi desa. Pengelolaan BUMDesa sepenuhnya dilaksanakan oleh masyarakat desa, yaitu dari desa, oleh desa, dan untuk desa. Cara kerja BUMDesa yaitu dengan jalan menampung kegiatankegiatan ekonomi masyarakat dalam sebuah bentuk kelembagaan atau badan usaha yang dikelola secara profesional, namun tetap bersandar pada potensi asli desa. Hal ini dapat menjadikan usaha masyarakat lebih produktif dan efektif. ${ }^{5}$

\footnotetext{
${ }^{4}$ Anom Surya Purba, Badan Usaha Milik Desa: Spirit Usaha Kolektif Desa (Kementrian Desa, Pembangunan Daerah Tertinggal, Dan Transmigrasi Republik Indonesia 2015) (2015).[4].

5 Reza M. Zulkarnaen, 'Pengembangan Potensi Ekonomi Desa Melalui Badan Usaha Milik Desa (BUMDES) Pondok Salam Kabupaten Purwakarta’ (2016) 5 Dharmakarya:Jurnal Aplikasi Ipteks untuk Masyaraka.[1].
} 
Di Indonesia pada umumnya, badan usaha dibedakan menjadi dua bentuk yaitu, badan usaha berbadan hukum seperti PT, Yayasan, dan Koperasi, dan badan usaha yang tidak badan hukum seperti CV dan UD.

Sedangkan BUMDesa secara spesifik tidak dapat disamakan dengan badan hukum seperti Perseroan Terbatas, CV, dan Koperasi. Oleh karena itu, BUMDesa merupakan suatu badan usaha bercirikan desa yang dalam pelaksanaan kegiatannya di samping untuk membantu penyelenggaraan Pemerintah Desa, juga untuk memenuhi kebutuhan masyarakat Desa. ${ }^{6}$

Berdasarkan peraturan perundang-undangan terkait tidak secara jelas menyatakan BUMDesa termasuk golongan badan usaha berbadan hukum atau badan usaha bukan badan hukum. Sampai disahkannya Undang-Undang Nomor 11 Tahun 2020 tentang cipta kerja. Dengan demikian penelitian ini akan membahas tentang konstruksi yuridis BUMDesa sebagai subyek hukum.

\section{Metode Penelitian}

Penulisan menggunakan hukum normatif. Penelitian berdasarkan pada penelitian doktrinal yaitu dengan menganalisis terhadap peraturan perundangundangan, yurisprudensi, dan kontrak-kontrak. Penelitian doktrinal digunakan untuk menganalisis asas-asas hukum, literatur hukum, pandangan para sarjana hukum yang memiliki konsep doktrinal, serta perbandingan hukum. ${ }^{7}$

Terdapat beberapa pendekatan yang digunakan antara lain pendekatan perundang-undangan (statue approach) dan pendekatan konseptual (conceptual approach). Pendekatan Undang-Undang (statute approach) dilakukan dengan menelaah semua undang-undang dan regulasi yang bersangkut paut dengan isu hukum yang sedang dijalani. ${ }^{8}$ Dalam penelitian ini akan dibahas, antara lain, Undang-Undang Nomor 5 Tahun 1960 dan Peraturan Menteri Agraria Nomor 18 Tahun 2016.

6 Oemar Moechthar, Teknik Pembuatan Akta "Badan Hukum Dan Badan Usaha Di Indonesia (Airlangga University Press 2019).[320].

7 Peter Mahmud Marzuki, 'Penelitian Hukum' (2001) 16 Yuridika.[104].

${ }^{8}$ Peter Mahmud Marzuki, Penelitian Hukum (Kencana Prenada Media Grup 2009).[93]. 
Pendekatan Konseptual (conceptual approach) dilakukan dengan cara menggunakan pandangan-pandangan dan konsep-konsep dari beberapa pemikir (ahli-ahli) serta doktrin-doktrin yang berkembang di dalam Ilmu Hukum sebagai dasar bagi penelitian ini guna membangun suatu argumentasi hukum dalam memecahkan isu hukum yang sedang diteliti. ${ }^{9}$ Dalam penelitian ini akan dibahas, antara lain, hak-hak atas tanah yang dikuasai oleh badan hukum dan peraturan perundang-undangan yang mengatur tentang batas maksimum penguasaan tanah oleh badan hukum.

\section{Karakteristik Badan Usaha Milik Desa}

Undang-Undang Nomor 32 Tahun 2004 juncto Undang-Undang Nomor 23 Tahun 2014 Tentang Pemerintah Daerah, Pasal 213 ayat (1) bahwa, "Desa dapat mendirikan badan usaha milik desa sesuai dengan kebutuhan dan potensi desa". Tujuannya adalah untuk mengakomodir potensi-potensi ekonomi yang terdapat di desa dengan harapan BUMDesa dapat menjadi wadah pemerintah dan warga desa untuk mengembangkan perekonomian desa.

Sesuai dengan peraturan perundang-undangan yang mengatur tentang BUMDesa sebelum disahkannya UU Cipta Kerja tidak menyebutkan apakah BUMDesa merupakan badan usaha berbadan hukum atau bukan. Untuk itu maka perlu dikaji kembali karakteristik BUMDesa. UU BumDesa Pasal 1 angka 6 Desa merupakan "badan usaha yang seluruh atau sebagian besar modalnya dimiliki oleh Desa melalui penyertaan secara langsung yang berasal dari kekayaan Desa yang dipisahkan guna mengelola aset, jasa pelayanan, dan usaha lainnya untuk sebesar-besarnya kesejahteraan masyarakat Desa." Permasalahan mengenai BUMDes yang belum berbadan hukum sangat menyulitkan bagi mereka untuk dapat mengakses permodalan, yang paling utama adalah dari bank-bank Himbara dimana kedudukan BUMDes belum diakui secara hukum.

${ }^{9}$ ibid.[137]. 
Berdasarkan Pasal 4 Peraturan Menteri Desa Nomor 4 Tahun 2015 BUMDesa didirikan berdasarkan Peraturan Desa (selanjutnya disebut Perdes) tentang Pendirian BUMDesayang disepakati melalui Musyawarah Desa. Pendirian BUMDesa harus melalui beberapa tahapan sebagaimana diatur pada Pasal 5 Permendes Nomor 4 Tahun 2015 sebagai berikut:

1. Musyawarah Desa

Musyawarah desa yang diadakan khusus dengan agenda pembahasana mengenai BUMDesa.

2. Pokok bahasan yang dibahas dalam musyawarah desa meliputi pendirian BUMDesa apakah sesuai dengan kondisi masyarakat Desa, Organisasi pengelolaan BUMDesa, dan pembahasan mengenai AD/ART BUMDesa.

3. Hasil dari musyawarah desa dapat dijadikan pedoman bagi pemerintah desa dan Badan Permusyawaratan Desa untuk membuat Perdes tentang Pendirian BUMDesa.

4. Setelah Perdes tentang Pendirian BUMDesa dibuat dan disahkan diumumkan pada Berita Acara Desa Oleh Sekretaris Desa.

5. Pemberitahuan kepada Bupati.

Di Indonesia terdapat penggolongan badan usaha yaitu, badan usaha yang berbadan hukum dan badan usaha yang tidak berbadan hukum. kedua bentuk badan usaha tersebut punya perbedaan yang sangat menonjol terutama pada pertanggung jawaban secara hukum. Pada badan usaha yang tidak berbadan hukum, pertanggung jawaban hukumnya terdapat pada para pendiri atau pengurusnya sebagai Naturlijk Persoon. Tidak terdapat pemisahan harta kekayaan sebagaimana yang bisa kita perhatikan pada badan usaha yang berbentuk CV dan UD.

Berbeda dengan badan usaha yang tidak berbadan hukum di atas, badan usaha berbadan hukum seperti PT, Koperasi, dan Yayasan mempunyai kedudukan hukum sendiri sebagai suatu "legal entity" yang memiliki legal standing yang melekat padanya sejak pendiriannya disahkan oleh kementrian. Pertanggung jawaban hukumnya terdapat pada badan hukum itu sendiri sebagai Recht Persoon.

Jadi, kapan atau bila dapat dikatakan adanya badan hukum itu tergantung pada syarat mana yang telah dipenuhi oleh perkumpulan, badan, atau badan usaha tersebut dan ini dapat dikaji dari sumber hukum formal, yaitu ada kemungkinan 
bahwa: ${ }^{10}$

1. Telah dipenuhi syarat yang ditetapkan oleh perundang-undangan;

2. Telah dipenuhi syarat yang ditetapkan oleh hukum kebiasaan;

3. Oleh yurisprudensi;

4. Oleh doktrin.

Suatu badan agar dapat dikategorikan sebagai badan hukum menurut Jimly Asshidiqie, harus memenuhi lima unsur, yaitu: ${ }^{11}$

1. Harta kekayaan yang terpisah dari kekayaan subyek hukum yang lain;

2. Unsur tujuan ideal tertentu yang tidak bertentangan dengan peraturan perundang-undangan;

3. Kepentingan sendiri dalam lalu lintas hukum;

4. Organisasi kepengurusannya bersifat teratur menurut peraturan perundangundangan yang berlaku dan peraturan internalnya sendiri;

5. Terdaftar sebagai badan hukum sesuai peraturan perundang-undangan yang berlaku.

Dari unsur-unsur di atas Jimly Asshidiqie juga membagi 5 unsur tersebut dalam unsur materiil dan unsur formil. Dimana unsur ke 1 sampai ke 4 adalah unsur materiil dan unsur ke 5 adalah unsur formil. Unsur-unsur tersebut bersifat kumulatif sehingga harus dipenuhi semuanya.

H.M.N Purwosujipto berpendapat mengenai syarat suatu badan usaha dapat digolongkan sebagai badan hukum yaitu: ${ }^{12}$

1. Harta kekayaan (hak-hak) dengan terpisah dengan kekayaan pribadi para sekutu atau pendiri badan. Hal ini dapat ditegaskan adanya pemisahan kekayaan perusahaan dengan kekayaan pribadi para sekutu;

2. Kepentingan bersama menjadi dasar kepentingan utama;

3. Pembentukan pengurus oleh beberapa orang dalam badan tersebut.

H.M.N Purwosujipto menyebutkan bahwa ketiga syarat tersebut merupakan syarat materiil pembentukan suatu badan usaha agar dapat digolongkan sebagai badan hukum, sedangkan syarat formil dari itu adalah pengakuan dari negara sehingga suatu badan usaha diakui sebagai badan hukum.

\footnotetext{
${ }^{10}$ Chidir Ali, Badan Hukum (Alumni 2014).[79].

11 Jimly Asshidiqie, Perkembangan dan Konsolidasi Lembaga Negara Pasca Reformasi, Setjen dan kepaniteraan MKRI (Sinar Grafika 2006).[77].

${ }^{12}$ H.M.N Purwosujipto, Pengertian Pokok Hukum Dagang Indonesia (Djambatan).[63]. dikutip dari Ridwan Khairandy, Perseroan Terbatas: Doktrin, Peraturan Perundang-Undangan dan Yurisprudensi (Total Media 2009).[10].
} 
Kemudian untuk menentukan apakah BUMDesa suatu badan usaha berbadan hukum atau badan usaha tidak berbadan hukum maka, perlu ditelaah apakah BUMDesa telah memenuhi unsur materiil dan formil badan hukum, yaitu sebagai berikut:

a) Syarat materiil

a. Harta kekayaan yang terpisah

Dalam definisinya disebutkan bahwa BUMDesa adalah badan usaha yang seluruh atau sebagian besar modalnya dimiliki oleh Desa melalui penyertaan yang berasal dari kekayaan Desa yang dipisahkan. Dengan demikian maka BUMDesa telah memenuhi syarat pertama yaitu harta kekayaan yang terpisah.

b. Adanya tujuan tertentu

Pada saat pembentukan BUMDesa melalui Musyawarah Desa telah ditentukan pula tujuan dari didirikannya BUMDesa, maka BUMDesa telah memenuhi syarat kedua yaitu adanya tujuan tertentu.

c. Mempunyai organisasi yang teratur BUMDesa mempunyai organisasi kepengurusan yang tertuang pada AD/ ART, serta diatur dalam perundang-undangan terkait diaman BUMDesa punya organ yaitu Penasihat, Pelaksana Operasional, dan Pengawas. Dengan demikian, maka BUMDesa telah memenuhi syarat ketiga yaitu mempunyai organisasi yang teratur.

b) Syarat formil

a. Permohonan Status Badan Hukum

Belum ada peraturan perundang-undangan yang mengatur mengenai permohonan status badan hukum BUMDesa. Sebelum disahkannya Undang-Undang Nomor 11 Tahun 2020 Tentang Cipta Kerja status badan hukum BUMDesa masih belum jelas.

Undang-Undang Nomor 11 tahun 2020 tentang Cipta kerja membawa peluang besar bagi BUMDesa. BUMDesa berada dalam bagian kelima tentang Perseroan Terbatas Pasal 7 Dengan disahkannya Undang-Undang Cipta Kerja 
memberikan kepastian hukum atas bentuk badan usaha BUMDesa. Pada Pasal 117 Undang-Undang Cipta kerja secara tegas mengganti definisi BUMDesa menjadi, “Badan Usaha Milik Desa, yang selanjutnya disebut BUM Desa adalah Badan Hukum yang didirikan oleh desa dan / atau bersama desa-desa guna mengelola usaha, memanfaatkan aset, mengembangkan investasi dan produktivitas, menyediakan jasa pelayanan, dan/atau menyediakan jenis usaha lainnya untuk sebesar-besarnya kesejahteraan masyarakat Desa."

UU Cipta Kerja memberikan posisi atau keberadaan BUMDes terlihat jelas sebagai badan hukum. Tentunya hal ini dapat memberi dampak yang besar bagi pengembangan BUMDes sebagai badan usaha yang dimiliki oleh desa.

\section{Kesimpulan}

Konstruksi hukum BUMDesa yang terpapar pada Undang-Undang Cipta kerja memberikan gambaran jelas tentang BUMDes yang ditetapkan menjadi Badan Hukum. Terkait dengan hal tersebut maka BUMDesa dituntut untuk lebih profesional untuk mendapat keuntungan yang nantinya dirasakan oleh seluruh masyarakat desa. Peran Pemerintah sangat dibutuhkan dalam pembentukan Sumber Daya Manusia sebagai tenaga kerja di desa yang mampu dalam mengembangkan BUMDesa.

Diharapkan dengan adanya BUMDesa yang berbentukbadan hukum mampu menjalankan fungsinya untuk menjadi motor penggerak dalam meningkatkan dan pemberdayaan ekonomi warga desa. Pemerintah memiliki peran penting untuk membuat aturan melalui PP terkait dengan kepemilikan agar BumDes berjalan sesuai harapan dan mampu mengatasi ketimpangan perekonomian yang terjadi antara desa dan kota.

\section{Daftar Bacaan}

\section{Buku}

Anom Surya Purba, Badan Usaha Milik Desa: Spirit Usaha Kolektif Desa: (Kementrian Desa, Pembangunan Daerah Tertinggal, Dan Transmigrasi Republik Indonesia 2015). 
Chidir Ali, Badan Hukum (Alumni 2014).

H.M.N Purwosujipto, Pengertian Pokok Hukum Dagang Indonesia (Djambatan) dikutip dari Ridwan Khairandy, Perseroan Terbatas: Doktrin, Peraturan Perundang-Undangan dan Yurisprudensi (Total Media 2009).

Jimly Asshidiqie, Perkembangan dan Konsolidasi Lembaga Negara Pasca Reformasi, Setjen dan kepaniteraan MKRI (Sinar Grafika 2006).

Oemar Moechthar, Teknik Pembuatan Akta "Badan Hukum dan Badan Usaha Di Indonesia." (Airlangga University Press 2019).

\section{Jurnal}

Maria Rosa Ratna Sri Anggraeni, 'Peranan Badan Usaha Milik Desa (BUMDES) Pada Kesejahteraan Masyarakat Pedesaaan Studi Pada Bumdes Di Gunung Kidul, Yogyakarta' (2016) Vol.28 No. 2 Jurnal Modus.

Reza M. Zulkarnaen, 'Pengembangan Potensi Ekonomi Desa Melalui Badan Usaha Milik Desa (BUMDES) Pondok Salam Kabupaten Purwakarta', (2016) Dharmakarya: Jurnal Aplikasi Ipteks untuk Masyarakat, Vol. 5, No. 1, Mei.

\section{Perundang-undangan}

Undang-Undang Nomor 32 Tahun 2004 juncto Undang-Undang Nomor 23 Tahun 2014 tentang Pemerintah Daerah.

Undang-Undang nomor 6 Tahun 2014 tentang Desa.

Undang-Undang Nomor 11 Tahun 2020 tentang Cipta kerja.

Peraturan Menteri Desa Nomor 4 Tahun 2015.

How to cite: Shara Mitha Mahfirah dan Adista Paramita, 'Kajian Normatif Kedudukan Badan Usaha Milik Desa Sebagai Subyek Hukum' (2021) Vol. 4 No. 1 Notaire. 